\title{
Phytoplankton composition in a neritic area of the Balearic Sea (Western Mediterranean)
}

\author{
J. VALENCIA-VILA ${ }^{1,3}$, M.L. FERNÁNDEZ DE PUELles ${ }^{1}$, J. JANSÁ ${ }^{1}$ AND M. VARELA ${ }^{2}$ \\ ${ }^{1}$ Instituto Español de Oceanografía, Muelle de Poniente s/n. 07015, Palma de Mallorca, Spain, ${ }^{2}$ Instituto Español de Oceanografía, \\ Paseo Alcalde Vázquez, 10. 15001, A Coruña, Spain, ${ }^{3}$ Present address: Instituto Español de Oceanografía, Paseo Alcalde Vázquez, 10. \\ 15001, A Coruña, Spain
}

\begin{abstract}
From September 2000 to September 2001 the concentration of chlorophyll a, and the abundance and composition of the phytoplanktonic community was studied in a neritic station of the Mallorca Channel (Western Mediterranean). Sampling was performed approximately every 12 days. Chlorophyll a concentration and phytoplankton abundance reached maxima of $1.79 \mu \mathrm{gL}^{-1}$ and 352 cells $m L^{-1}$, respectively. It was a relatively productive period, as a result of the high convective mixing in winter and the prevalence of northern waters during most of the cycle. Phytoplankton proliferations (chlorophyll a concentration $>1 \mathrm{mg} \mathrm{L}^{-1}$ ) were detected in January, February, March and June. Those blooms mainly happened under the influence of northern waters, with the exception of the February proliferation, when mixing conditions were found. During bloom conditions it highlights the presence of coccolithophores as proliferation precursors. During no-bloom situations the phytoplankton community was mainly constituted by nanoplanktonic flagellated forms. The Winter Mixing period was dominated by different groups of nanoflagellates, including coccolithophores, undetermined flagellates and dinoflagellates. However, in the most oligotrophic conditions (from April until November) dinoflagellates were clearly dominant, except in the DCM in summer where diatoms prevailed.
\end{abstract}

Keywords: phytoplankton, annual cycle, bloom, Balearic Islands, Western Mediterranean

Submitted 22 July 2014; accepted 19 June 2015

\section{INTRDDUCTIDN}

The Balearic Islands form a topographic barrier separating two sub-basins, the North-western Basin and the Algerian Basin, where different water masses pass through. Atlantic Water (recent AW) dominates the surface layer of the Algerian Basin, while the saltier Mediterranean Surface Water (MW) is prevalent in the North-western Basin (Pinot et al., 2002). Different processes such as the formation of deep water in the Gulf of Lions (Estrada et al., 1985), permanent frontal systems (Estrada \& Salat, 1989) and river run-off serve to increase primary production in the North-western Basin, causing MW to have a higher concentration of nutrients than recent AW when they meet in the Balearic Sea (Fernández de Puelles \& Molinero, 2007). Circulation through the Balearic Channels is complex due to mesoscale processes (Pinot et al., 2002). In general, the Ibiza Channel funnels MW as it moves southward, while the Mallorca Channel is the main route for the northward progression of recent AW. However, seasonal or interannual variation of this general scheme has been observed. Severe conditions intensify the Northern Current increasing the presence of MW in the Mallorca Channel.

Winter or early spring phytoplankton blooms are characteristic of the Mediterranean (Siokou-Frangou et al., 2009). These increases are generally triggered by periods of high atmospheric pressure, causing an interval of stable water

Corresponding author:

J. Valencia-Vila

Email: joaquin.valencia@co.ieo.es column. The rapid growth of the phytoplankton is then stimulated by this transient stratification of the water column, together with the presence of nutrients in the euphotic layer due to previous winter mixing (Duarte et al., 1999). In the Mallorca Channel phytoplankton blooms usually take place in January-February as well as in May (Fernandez de Puelles et al., 2007).

The pattern of phytoplankton succession was originally described by Margalef (1958, 1963a, b), using samples partly from the Western Mediterranean. Three stages were defined (Margalef, 1963a; Smayda, 1980). Stage I, typical of turbulent and nutrient-enriched waters, is dominated by species with fast replication rates, including nanoflagellates and fastgrowing diatoms. Stage II includes larger diatoms with lower growth rates and dinoflagellates. At the end of this stage, in addition to slow-growing diatoms, there is an increase in the presence of dinoflagellates and coccolithophores. Some authors consider this final phase of Stage II as an independent stage (Smayda, 1980). Stage III takes place when the water column is well stratified and the nutrients decrease. It is characterized by motile species with low growth rates, particularly dinoflagellates.

The objective of this study is to describe the variation in phytoplankton composition in a neritic area of the Mallorca Channel (Balearic Islands) during an annual cycle.

\section{MATERIALS AND METHDDS}

From September 2000 to September 2001 a station, $77 \mathrm{~m}$ depth, located on the southern shelf of Mallorca Island 


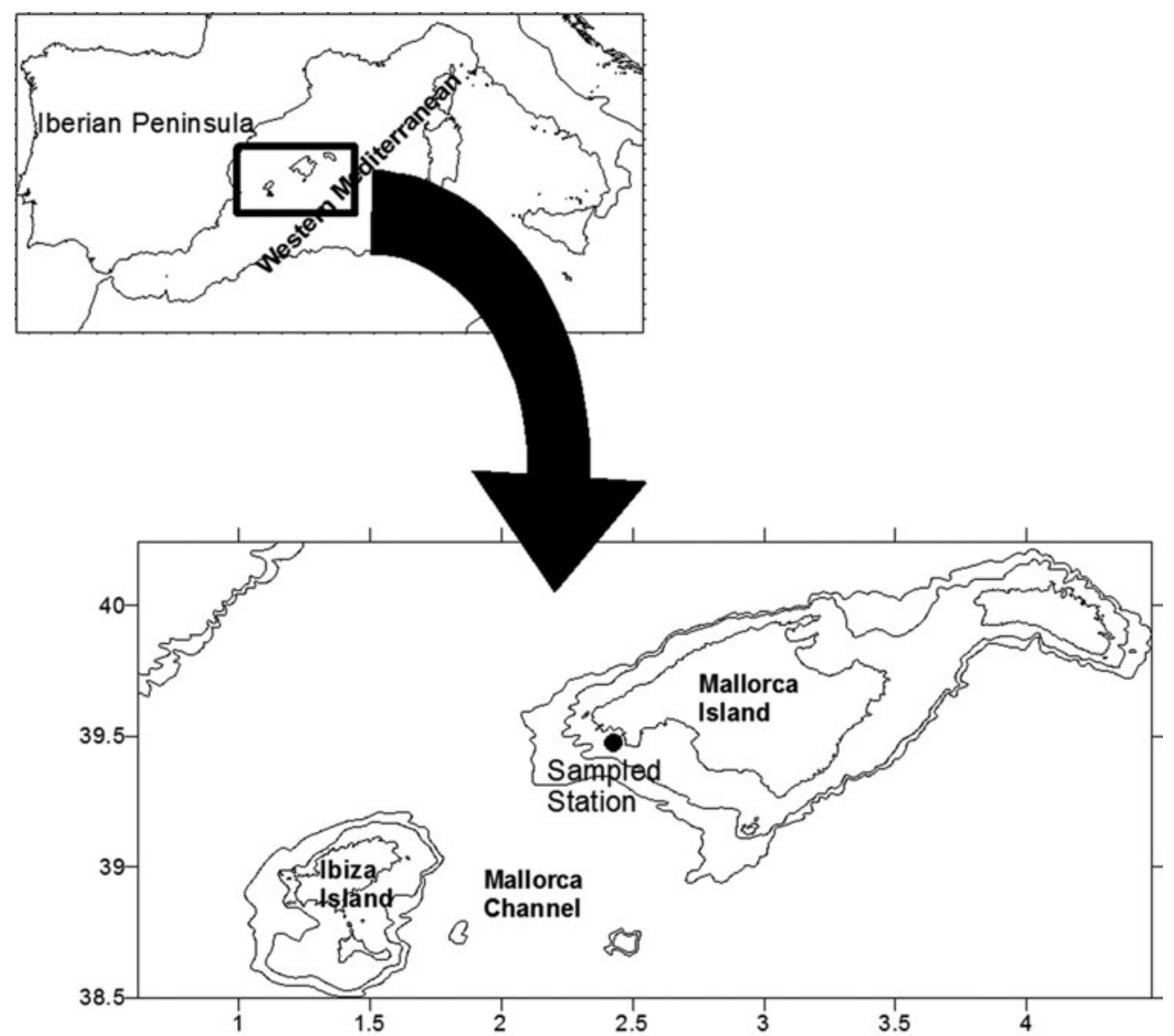

Fig. 1. Map of the study area with location of the sampling station.

(Figure 1) was sampled approximately every 12 days. Water samples were collected at fixed depths of 5, 15, 25, 50 and $75 \mathrm{~m}$ using $5 \mathrm{~L}$ Niskin bottles. CTD data were recorded with a CTD Seabird 19 or CTD Seabird 25, calibrated every 2 years.

Water samples for the determination of nutrients were collected from the Niskin bottles and immediately frozen to $-20^{\circ} \mathrm{C}$ until the laboratory analysis of nitrates+nitrites $\left(\mathrm{NO}_{\mathrm{x}}\right)$ and silicates (Armstrong et al., 1967).

Chlorophyll $a$ concentrations were determined using the fluorometric technique (Holm-Hansen et al., 1965) after the filtration of $1500 \mathrm{~mL}$ of seawater through Whatman GF/C filters. Chlorophyll was extracted with $90 \%$ acetone and measured using a Perkin-Elmer 204 spectrofluorimeter (UNESCO, 1966). Samples for phytoplankton counts were preserved with $4 \%$ formaldehyde neutralized with hexamethylenetetramine and examined with an inverted microscope following Uterhmöhl's method (Sournia, 1978). As a general rule, three depths were analysed from each sample, corresponding to the chlorophyll maximum and the levels situated above and below that maximum. In cases where the chlorophyll maximum was located at the bottom, the two upper levels were also analysed. Subsamples of 50 or $100 \mathrm{~mL}$ were sedimented in a composite chamber before examination. Magnification powers of $\times 100, \times 250$ and $\times 400$ were used depending on the size of the organisms. Many organisms could not be identified at the genus or species level and were placed in general categories, for example: dinoflagellates $<20 \mu \mathrm{m}$, flagellates $<_{20} \mu \mathrm{m}$, coccolithophores $<_{20} \mu \mathrm{m}$.

\section{RESULTS}

\section{Water column conditions}

Four oceanographic periods were recognized according to the stratification of the water column (Figure 2). The Winter Mixing period started in January and lasted until the middle of March, and was characterized by homothermal conditions. The Spring Transition period began in the middle of March with the establishment of the thermocline and finished at the end of May. The Summer Stratification period occurred in September 2000 and from June to September 2001, and was characterized by a strong thermal stratification. Finally, the Autumn Transition period lasted between October and the end of December 2000, when the thermocline was eroded.

Salinity was generally higher in winter than in summer even though there was no clear seasonal pattern (Figure 2). During the Winter Mixing and the first half of the Spring Transition salinity was close to 38 , except in late February when a pronounced decrease was observed. During the second half of the Spring Transition, Summer Stratification and Autumn Transition the salinity in the higher layer (upper $25-70 \mathrm{~m}$ ) was less than 37.7 . At the beginning of June there was a rise in salinity in the lower part of the column with values over 38.1 below $68 \mathrm{~m}$.

During the Winter Mixing (Figure 3) the concentration of $\mathrm{NO}_{\mathrm{x}}$ was higher than $1 \mu \mathrm{M}$ in the entire water column, except at the end of February when the values were lower than $0.1 \mu \mathrm{M}$ in most layers. During the Spring Transition surface 
A Temperature $\left({ }^{\circ} \mathrm{C}\right)$


Fig. 2. Distribution of temperature (A) and salinity (B) during the study. Vertical arrows indicate the sampling dates. SS, Summer Stratification; AT, Autumn Transition; WM, Winter Mixing; ST, Spring Transition.

concentrations decreased to less than $0.2 \mu \mathrm{M}$. In the Summer Stratification $\mathrm{NO}_{\mathrm{x}}$ values were less than $0.2 \mu \mathrm{M}$ in most of the water column. Meanwhile, the bottom concentration usually was above $2 \mu \mathrm{M}$, with a noteworthy increase of up to $4.8 \mu \mathrm{M}$ in the bottom concentration in early June. On the contrary, the bottom concentration was less than 1.1 $\mu \mathrm{M}$ in August. In the Autumn Transition period the $\mathrm{NO}_{\mathrm{x}}$ concentration increased, especially in the bottom layer, with values higher than $3 \mu \mathrm{M}$.

Silicates increased on the surface during the Winter Mixing period, reaching values above $2 \mu \mathrm{M}$ in most of the water column in early March, but decreased thereafter, particularly in the bottom layer (Figure 3). In May, silicate concentrations rose at the $75 \mathrm{~m}$ level, achieving the maximum concentration in early June $(4.0 \mu \mathrm{M})$. During the rest of the Summer Stratification silicate concentration at the bottom level fluctuated between 2.7 and $0.6 \mu \mathrm{M}$. In the Autumn Transition the concentration of silicate increased mainly at the $50-75 \mathrm{~m}$ layer with values between 2 and $3.6 \mu \mathrm{M}$.

\section{Phytoplankton blooms}

In this study a phytoplankton bloom was deemed to exist when the maximum chlorophyll concentration in the water column was higher than $1 \mu \mathrm{g} \mathrm{L}^{-1}$. Therefore, proliferations occurred in January, February, March and early June
(Figure 4). January, February and March bloom values reached around $1.5 \mu \mathrm{g} \mathrm{L}^{-1}$. In the second half of March the maximum concentration was still above $0.9 \mu \mathrm{g} \mathrm{L}^{-1}$. During the rest of the Spring Transition the values tended to decline and the chlorophyll maximum was found at deeper levels, forming a distinct deep chlorophyll maximum (DCM). In early June another bloom was found with values over $1 \mu \mathrm{g} \mathrm{L}^{-1}$ at $50 \mathrm{~m}$. Twelve days later, the concentration of chlorophyll was still quite high $\left(0.9 \mu \mathrm{g} \mathrm{L}^{-1}\right)$ although the maximum had moved to $75 \mathrm{~m}$. During the rest of the Summer Stratification (including September 2000) the DCM was found near the bottom with values ranging between 0.46 and $0.72 \mu \mathrm{g} \mathrm{L}^{-1}$, while in the upper $25 \mathrm{~m}$ the concentration was less than $0.25 \mu \mathrm{g} \mathrm{L}^{-1}$. At the beginning of the Autumn Transition the chlorophyll maximum was located at the $50 \mathrm{~m}$ level with values of $0.32-0.45 \mu \mathrm{g} \mathrm{L}^{-1}$. From the end of November until the end of December the chlorophyll maximum was situated at the $25 \mathrm{~m}$ level with concentrations between 0.49 and $0.6 \mu \mathrm{g} \mathrm{L}^{-1}$.

\section{Phytoplankton abundance and composition}

Table 1 shows the taxons with the highest frequency of occurrence. During the Winter Mixing period phytoplankton comprised mainly coccolithophores, flagellates and dinoflagellates of nanoplanktonic size, with none of these groups being clearly dominant 
A $\mathrm{NO}_{\mathbf{x}}(\mu \mathrm{M})$
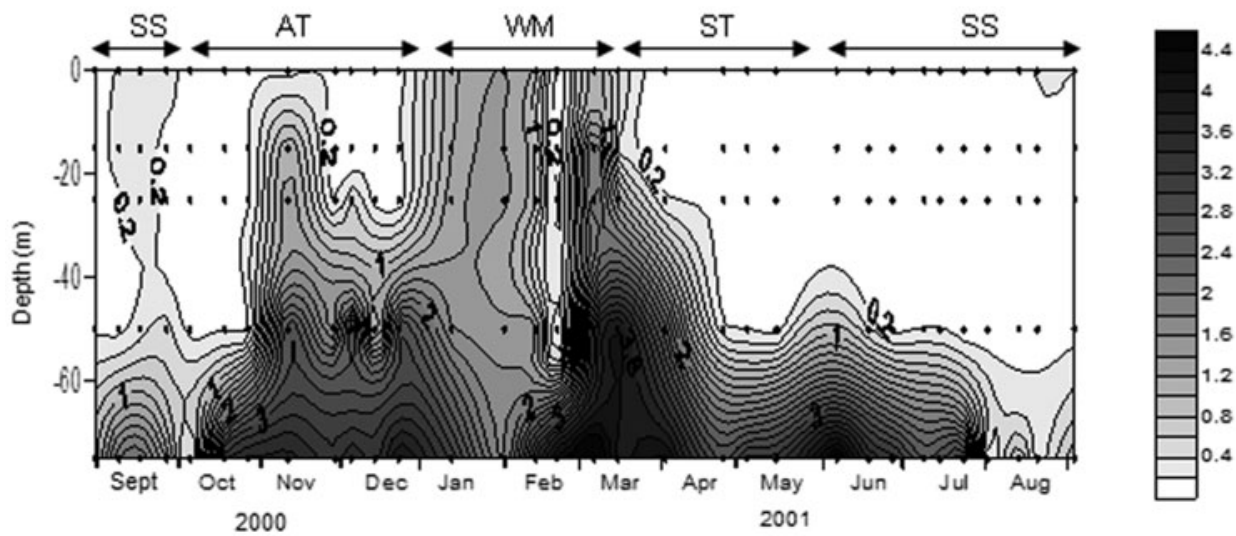

B $\mathrm{SiO}_{2}(\mu \mathrm{M})$

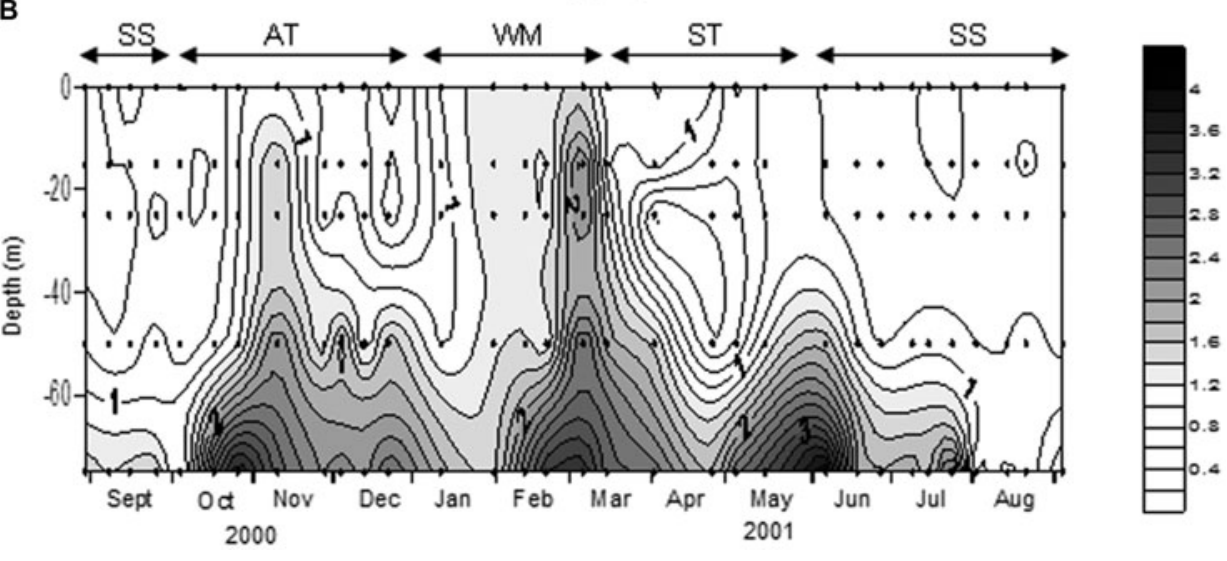

Fig. 3. Distribution of $\mathrm{NO}_{\mathrm{x}}$ (A) and silicate concentration (B). Dots indicate the depths sampled by Niskin Bottles. SS, Summer Stratification; AT, Autumn Transition; WM, Winter Mixing; ST, Spring Transition.

(Figures 5 and 6). Diatoms were only occasionally important as in the first proliferation. In the January bloom a maximum of 272 cell $\mathrm{mL}^{-1}$ was observed (Figure 4), made up of coccolithophores, diatoms and nanoflagellates. These diatoms mainly belong to the species Lauderia annulata, Rhizosolenia spp., Thalassionema nitzschioides and Leptocylindrus danicus. On the other hand, the February proliferation reached $309 \mathrm{cell} \mathrm{mL}^{-1}$ and was dominated by nanoflagellates and nanodinoflagellates. In early March a new bloom started, composed primarily of coccolithophores and nanoflagellates.

During the rest of March, the bloom conditions detected at the end of the Winter Mixing continued, with maxima $>_{128}$ cells $\mathrm{mL}^{-1}$ mainly formed by diatoms, nanoflagellates and nanodinoflagellates. The diatoms during this bloom were represented by Pseudo-nitzschia 'delicatissima group', Thalassionema nitzschoides, Rhizosolenia spp. and Chaetoceros pseudocurvisetus. In April and May the community was dominated by dinoflagellates $<20 \mu \mathrm{m}$, highlighting a marked decline in abundance in May to less than 62 cells $\mathrm{mL}^{-1}$.

At the beginning of the Summer Stratification another bloom took place with values of 352 cells $\mathrm{mL}^{-1}$ at $50 \mathrm{~m}$. This peak was formed mainly by coccolithophores and nanodinoflagellates (Figure 6). During the rest of the Summer Stratification and in contrast to chlorophyll, the maximum abundance was not generally found near the bottom, but rather in the middle of the water column. In this period, phytoplankton abundance was usually under 62 cells $\mathrm{mL}^{-1}$.
At the end of this period abundance was normally $<50$ cell $\mathrm{mL}^{-1}$. The typical summer situation was characterized by the clear dominance of nanodinoflagellates in most of the water column, except in the bottom where diatoms tended to be dominant (Figure 6). These diatoms were mainly formed by pennates $>20 \mu \mathrm{m}$, Thalassionema nitzschoides and Pseudo-nitzschia 'seriata group'.

During October and the first half of November phytoplankton abundance was usually under 50 cells $\mathrm{mL}^{-1}$ and consisted mainly of nanoflagellates, nanodinoflagellates and coccolithophores. From the end of November there was an increase in the abundance of phytoplankton, so that in early December values over 100 cells $\mathrm{mL}^{-1}$ were found. From late November to late December the phytoplankton community was dominated by coccolithophores, followed by nanoflagellates and nanodinoflagellates. During this period the number of diatoms increased, becoming the second most abundant group (after coccolithophores) at the end of December.

\section{DISCUSSIDN}

\section{Environmental conditions}

According to the description of water masses in the Balearic Sea made by López-Jurado et al. (1996), salinities over 37.5 indicate the presence of MW. Therefore, northern waters 
A

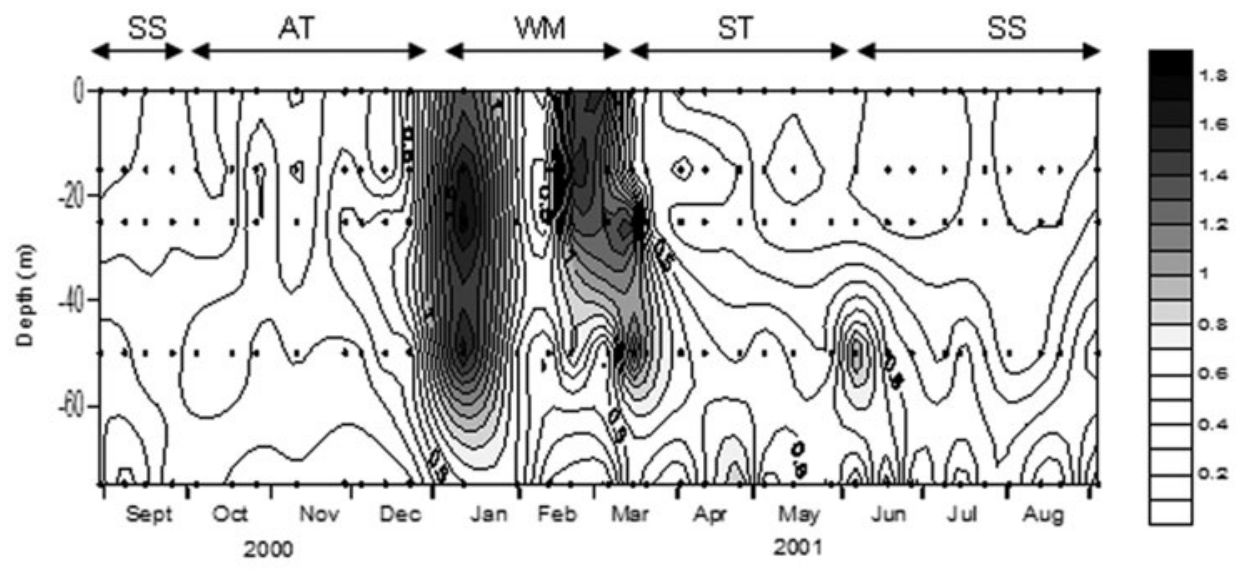

B

\section{Phytoplankton abundance (cells $\mathrm{ml}^{-1}$ )}

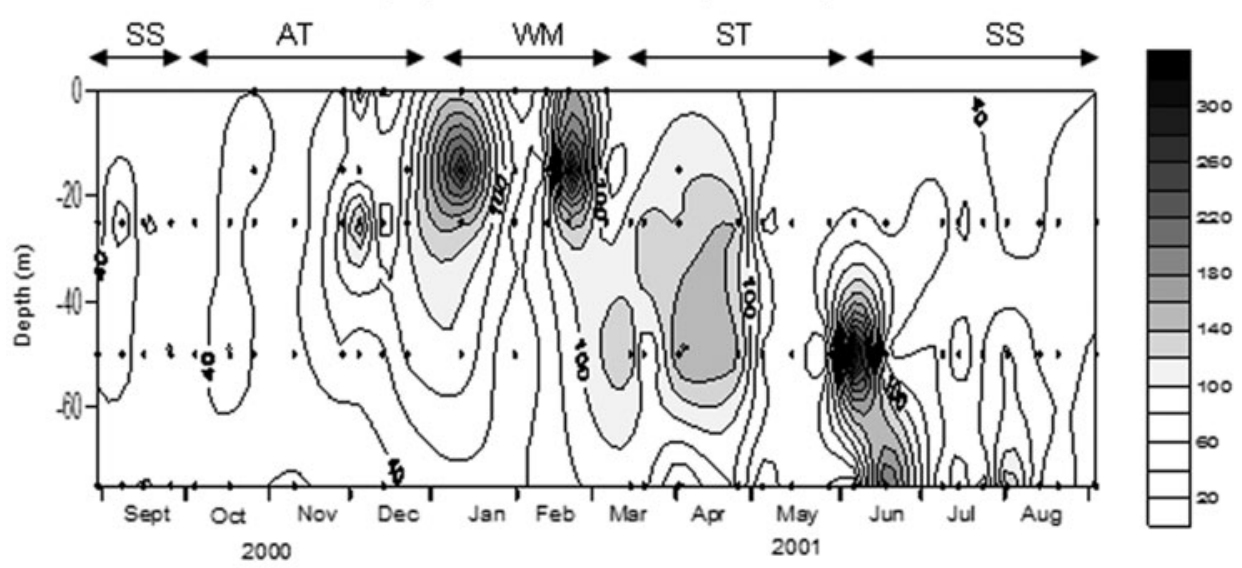

Fig. 4. Distribution of chorophyll a concentration (A) and phytoplankton abundance (B) during the study. Dots indicate the depths sampled by Niskin Bottles for each variable. SS, Summer Stratification; AT, Autumn Transition; WM, Winter Mixing; ST, Spring Transition.

were dominant during most of the year studied. The recent AW, with a lower salinity, appeared mainly in August, September and October and in the surface layer in May-June.

The surface salinity suggests the absence of any important terrestrial influence, as was already observed for the area (Fernandez de Puelles et al., 1997; Jansá, 2008). This is mainly due to the nonexistence of permanent rivers in the Mallorca Island and the situation of the studied station in open waters.

Compared with the historical data in the sampled station (1994-2003; Fernández de Puelles et al., 2007), autumn 2000 and winter 2001 were colder than average for these seasons. Moreover, salinity values and the concentration of nutrients during the year studied were higher than average (Fernández de Puelles et al., 2007). Other studies stressed the importance of colder and saltier years for the primary production in the area (Estrada et al., 1985), since convective mixing reaches a deeper layer and the presence of MW in the Mallorca Channel is intensified (Fernández de Puelles \& Molinero, 2007). In fact in 2000 and 2001 the maximum average of chlorophyll concentration of the data series was obtained (Fernández de Puelles et al., 2003, 2007).

\section{Phytoplankton}

According to the historical data, the Mallorca Channel characteristically exhibits chlorophyll maxima in January-February and in May (Fernandez de Puelles et al., 1997, 2007). This is consistent with the blooms observed in January, February and June. However the March bloom found in this study is unusual in the area, and would probably be related to the great influence of MW in the Mallorca Channel during the thermocline formation. Before the January proliferation, a rise in air temperature and an absence of strong winds in the days prior to the event were observed (Valencia-Vila, 2013). These circumstances may have favoured the stability of the water column. The formation of a transient thermocline, in the middle of a mixing season with high nutrient concentrations, resulted in the bloom observed. Considering the prevalence of MW at that date, the bloom could have originated northerly from the sampling station. The sea conditions did not allowed an intensive sampling that month. At the next date no bloom conditions were found, as the return to the mixing conditions had probably interrupted the succession sequence. The February bloom was associated with a clear decrease in salinity, due to the input of southern waters which mix with northern waters. The proliferation could have been transported from the south or have developed in situ as a consequence of the mixing of the two water masses. This maximum coincided with a decline in $\mathrm{NO}_{\mathrm{x}}$ concentration. A rise in the zooplankton biomass was also observed at this time (Fernández de Puelles et al., 2007; Valencia-Vila, 2013). This is typical of an advanced stage of the proliferation 
Table 1. Taxons with a frequency of occurrence $>_{15} \%$. Freq: percentage of samples with presence of each taxon. Mean: mean average (cell $\mathrm{mL}{ }^{-1}$ ). SD: standard error. Max: maximum average (cell $\mathrm{mL}^{-1}$ ) and month of the maximum (in parentheses).

\begin{tabular}{|c|c|c|c|c|}
\hline Taxon & Freq. (\%) & Mean & SD & Max. \\
\hline Dinoflagellates $<20 \mu \mathrm{m}$ & 99.1 & 17.82 & 1.40 & 88.o (Jun) \\
\hline Undetermined flagellates $<\mathbf{2 0} \mu \mathrm{m}$ & 98.1 & 12.47 & 1.53 & $117.9(\mathrm{Feb})$ \\
\hline Coccolithophores $<20 \mu \mathrm{m}$ & 91.5 & 12.20 & 1.78 & 113.0 (Jun) \\
\hline Dinoflagellates $>20 \mu \mathrm{m}$ & 84.0 & 1.60 & 0.31 & 29.5 (Mar) \\
\hline Udetermined flagellates $>20 \mu \mathrm{m}$ & 83.0 & 1.64 & 0.26 & 19.6 (Apr) \\
\hline Pennates $>20 \mu \mathrm{m}$ & 76.4 & 1.52 & 0.25 & 14.0 (Jun) \\
\hline Centrics $>20 \mu \mathrm{m}$ & 72.6 & 0.35 & 0.10 & 9.0 (Jun) \\
\hline Cryptophyceae undet. & 68.9 & 4.33 & 0.75 & $47.2(\mathrm{Feb})$ \\
\hline Protoperidinium spp. & 65.1 & 0.12 & 0.02 & $1.5(\mathrm{Dec})$ \\
\hline Oxytoxum spp. & 57.6 & 1.19 & 0.18 & 8.8 (May) \\
\hline Rhizosolenia spp. & 52.8 & 1.05 & 0.23 & $13 \cdot 3$ (Jan) \\
\hline Thalassionema nitzschioides & 51.9 & 1.82 & 0.49 & 42.1 (Jun) \\
\hline Undetermined Gymnodiales & 49.1 & 0.36 & 0.07 & 4.0 (Apr) \\
\hline Gyrodinium fusus & 49.1 & 0.17 & 0.04 & 2.3 (Sep) \\
\hline Gyrodinium spp. & 48.1 & 0.17 & 0.04 & 3.2 (Mar) \\
\hline Neoceratium fusus & 40.6 & 0.17 & 0.04 & 2.0 (Jun) \\
\hline Thoracosphaera heimii & 40.6 & 0.01 & 0.00 & 0.1 (Jun) \\
\hline Pseudo-nitszchia seriata group & 40.6 & 0.25 & 0.04 & 2.0 (Jun) \\
\hline Lioloma pacificum & 39.6 & 1.71 & 0.41 & $31.6(\mathrm{Dec})$ \\
\hline Dictyocha fibula & 39.6 & 0.07 & 0.03 & 2.6 (Nov) \\
\hline Centrics $<20 \mu \mathrm{m}$ & 37.7 & 0.39 & 0.07 & $3 \cdot 3$ (Jun) \\
\hline Helicosphaera carteri & $37 \cdot 7$ & 0.44 & 0.11 & 8.0 (Jun) \\
\hline Syracosphaera pulchra & 28.3 & 0.37 & 0.09 & 5.9 (Jun) \\
\hline Calciosolenia brasiliensis & 26.4 & 0.19 & 0.04 & $2.0(\mathrm{Jan})$ \\
\hline Scripsiella like & 25.5 & 0.39 & 0.10 & 6.0 (Sep) \\
\hline Umbilicosphaera sibogae Var sibogae & 25.5 & 0.25 & 0.06 & 3.3 (May) \\
\hline Phaeocystis cf. globosa & 25.5 & 0.07 & 0.02 & $1.3(\mathrm{Jan})$ \\
\hline Umbilicosphaera sibogae Var foliosa & 24.5 & 0.95 & 0.35 & $29.3(\mathrm{Feb})$ \\
\hline Pennates $<\mathbf{2 0} \mu \mathrm{m}$ & 23.6 & 0.12 & 0.03 & $2.0(\mathrm{Feb})$ \\
\hline Proboscia alata & 22.6 & 0.23 & 0.06 & 4.0 (Jun) \\
\hline Neoceratium furca & 21.7 & 0.13 & 0.05 & 4.5 (Dec) \\
\hline Prorocentrum compressum & 21.7 & 0.01 & 0.00 & $0.1(\mathrm{Feb})$ \\
\hline Prorocentrum micans & 21.7 & 0.01 & 0.00 & 0.3 (Aug) \\
\hline Coclhodinium spp. & 20.8 & 0.01 & 0.00 & 0.3 (Nov) \\
\hline Torodinium robustum & 20.8 & 0.01 & 0.01 & 0.4 (Mar) \\
\hline Hemiaulus hauckii & 20.8 & 0.01 & 0.00 & 0.2 (Apr) \\
\hline Chaetoceros spp. & 19.8 & 0.18 & 0.11 & $11.0(\mathrm{Jul})$ \\
\hline Guinardia striata & 19.8 & 0.30 & 0.12 & 8.o (Jun) \\
\hline Calciosolenia murrayi & 19.8 & 0.26 & 0.08 & 7.0 (Jun) \\
\hline Solenicola setigera & 19.8 & 0.32 & 0.12 & 10.5 (Sep) \\
\hline Lauderia annulata & 17.9 & 4.14 & 1.53 & 87.9 (Aug) \\
\hline Odontella mobiliensis & 17.0 & 0.46 & 0.25 & $23.9(\operatorname{Jan})$ \\
\hline Pleurosigma spp. & 17.0 & 0.10 & 0.04 & $2.5($ Sep $)$ \\
\hline Dinophysis cf. rotundata & 16.0 & 0.02 & 0.01 & 1.0 (Jun) \\
\hline Diploneis spp. & 16.0 & 0.01 & 0.00 & 0.3 (May) \\
\hline Oxytoxum scolopax & 15.1 & 0.05 & 0.01 & 0.7 (Aug) \\
\hline Guinardia flaccida & 15.1 & 0.01 & 0.00 & 0.3 (Aug) \\
\hline Pseudolenia calcar-avis & 15.1 & 0.11 & 0.06 & $4.9(\mathrm{Jul})$ \\
\hline Algirosphaera cf. robusta & 15.1 & 0.08 & 0.04 & $3 \cdot 5$ (Jan) \\
\hline
\end{tabular}

where the phytoplankton had depleted the nutrients and the zooplankton had had enough time to respond to the increase in microalgae. The dominance of flagellates and dinoflagellates during this proliferation also suggests a mature stage of the proliferation, although it must be taken into account that recent AW could host a different community. Variations in the environmental conditions (mainly salinity and $\mathrm{NO}_{\mathrm{x}}$ ) after this bloom indicate another change in the water masses, and therefore, the phytoplankton succession sequence was interrupted. Finally, the June proliferation was associated with water cooling in the deep layer, along with an increase in salinity and nutrient concentration near the bottom, pointing to the input of northern waters. In May and June 2001 a clear front was observed south of the sampling station (Fernández de Puelles et al., 2004; Alemany et al., 2010), preventing the input of waters of Atlantic origin and allowing the presence of northern waters in the sampled area.

Defining the succession from a fixed point is always a problem (Margalef, 1963b), especially in the studied area where two different water masses pass through. In any case, the observed changes in phytoplankton composition are schematized in Figure 7 . During no-bloom situations 


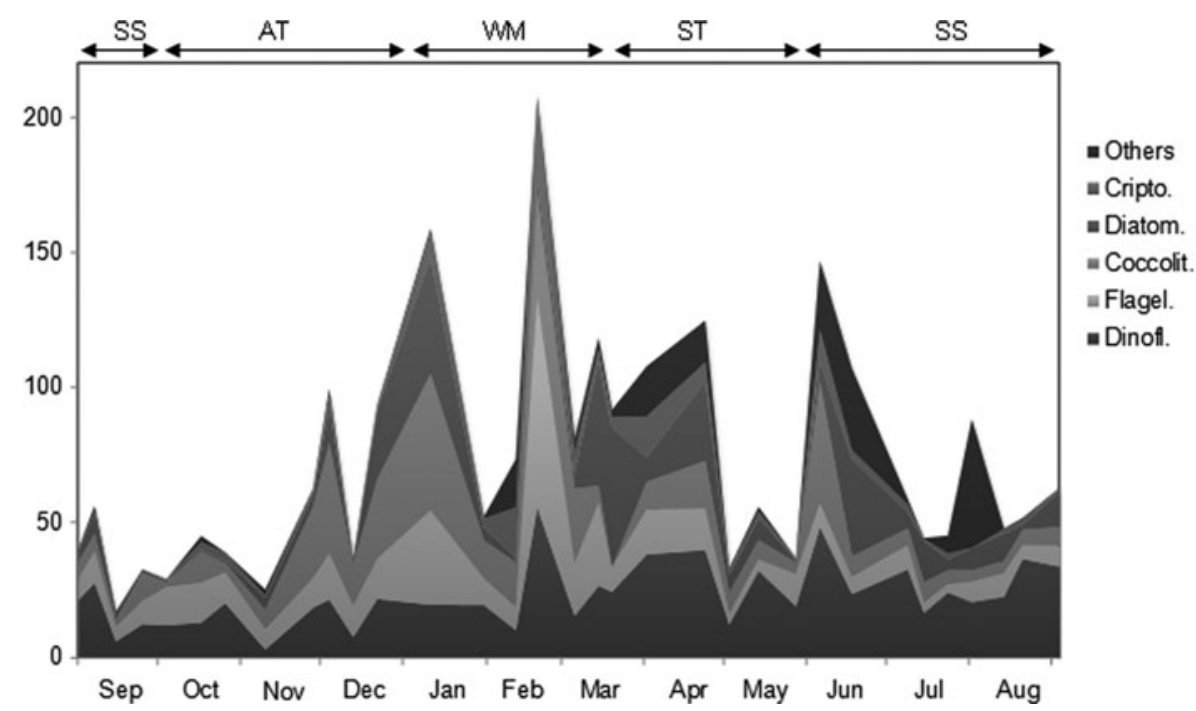

Fig. 5. Variation of the main taxonomic groups during the study. Others: other groups. Crypto: cryptophyceans. Diatom: diatoms. Coccolit: coccolithophores. Flagel: undetermined flagellates. Dinofl: dinoflagellates. SS, Summer Stratification; AT, Autumn Transition; WM, Winter Mixing; ST, Spring Transition.

phytoplankton is dominated by nanoplanktonic flagellated forms. This circumstance suggests a prevalence of the microbial food web (sensu Legendre \& Rassoulzadegan, 1995) during most of the year studied, as has already been highlighted for the entire Mediterranean Sea (Siokou-Frangou et al., 2009).

The Winter Mixing was dominated by nanoflagellates (coccolithophores, undetermined flagellates and dinoflagellates). Among flagellates it is known, from HPLC studies, that prymnesophyceans often represent an important group in the Mediterranean (Siokou-Frangou et al., 2009). In fact, in the nearby Bay of Andratx the genus Chrysochromulina was dominant between December and April (Puigserver, 2003). Moreover, the remarkable presence of coccolithophores, specifically Emiliania huxleyi, during winter in the Mediterranean has been observed in other studies (see compilation in Siokou-Frangou et al., 2009).

In the oligotrophic conditions (from Mid Spring Transition to Mid Autumn Transition) dinoflagellates were the most prevalent group. Estrada et al. (2014), in situations of postbloom and summer stratification in MW, also found a dominance of dinoflagellates accompanied by coccolithophores, who also were important in our study. However, in a HPLC study in a post-bloom situation in recent $\mathrm{AW}$ a community dominated by Shynechococcus and primnesoficeans was found (Gutiérrez et al., 2010). This discrepancy with our study can be attributed to methodological differences, together with spatial and temporal heterogeneity.

On the other hand, diatoms prevailed during the Summer Stratification in the DCM, as was already observed in Western Mediterranean in southern waters (Ros and Miracle, 1984) and northern waters (Estrada et al., 1993). The dominance of diatoms in the summer DCM was not continuous, probably due to the fluctuating concentrations of silicates which cause intermittent events of silicate limitation. Other studies also reported the irregular dominance of diatoms in the DCM (Estrada et al., 1993).

The increasing abundance in mid Autumn Transition and the change towards a coccolithophores prevalence was related with the higher concentration of nutrients, caused by the increasing convective mixing and the greater presence of WM. The importance of coccolithophores in late Autumn Transition has already been reported in the Mediterranean (Siokou-Frangou et al., 2009).

The influence of the water masses in the phytoplankton composition was masked by the annual cycle of phytoplankton, and it is not as clear as in the zooplankton (Fernández de Puelles et al., 2004). Even though, proliferations used to appear with the prevalence of WM, with the important exception of the February bloom. As recent AW was associated with oligotrophic conditions, its presence was normally related with the domain of small dinoflagellates, like in surface waters during the Summer Stratification and the Autumn Transition.

Regarding the proliferations, the importance must be highlighted of coccolithophores and other flagellates (including dinoflagellates) during the beginning of the blooms, when the nutrient concentrations were still relatively high. This was observed in January, early March and early June. During these proliferations, coccolithophores were most likely formed mainly by Emiliania huxleyi, as it is an important bloom-forming species (Tyrrell \& Merico, 2004), although the presence of other bloom-forming species such as Gephyrocapsa oceanica (Guerreiro et al., 2013) cannot be ruled out. Other studies also found coccolithophores in early stages of the bloom. Some studies reported high quantities of settled coccoliths of Emiliania huxleyi and Gephyrocapsa oceanica during or just after upwelling pulses (Mergulhao et al., 2006; Silva et al., 2008). In central Portugal a late winter bloom was found with high densities of these E. huxleyi together with Margalef s Stage I diatoms genera (Chaetoceros, Thalassiosira and Skeletonema; Guerreiro et al., 2013), similar to our January bloom. Consequently, considering these studies and our own results, the coccolithophores should be regarded as possible early successors, as was emphasized by Guerreiro et al. (2013).

Only in the January bloom did diatoms develop together with coccolithophores and flagellates. In the March and June blooms, the development of diatoms was detected later and it was characterized by relatively slow-growing diatoms 
A Dinoflagellates (cells $\mathrm{ml}^{-1}$ )
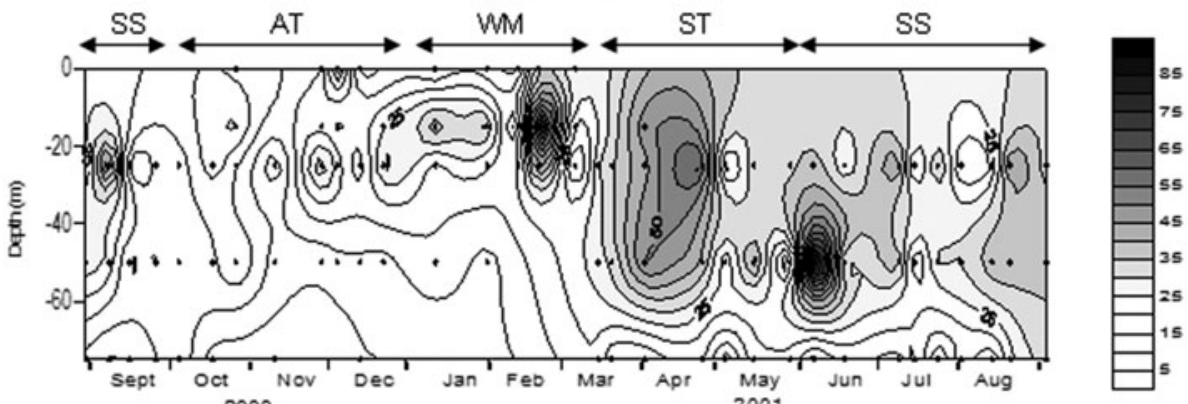

Flagellates (cells $\mathrm{ml}^{-1}$ )

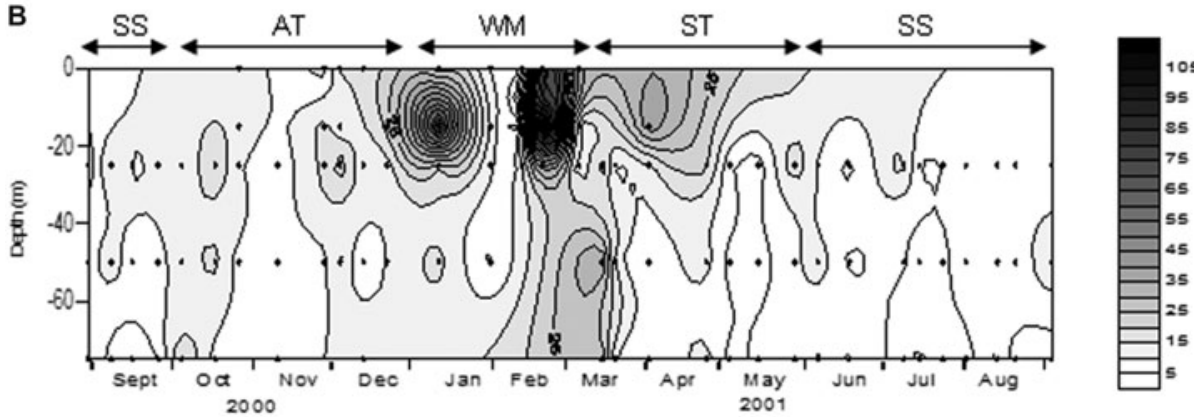

Coccolithophores (cells $\mathrm{ml}^{-1}$ )
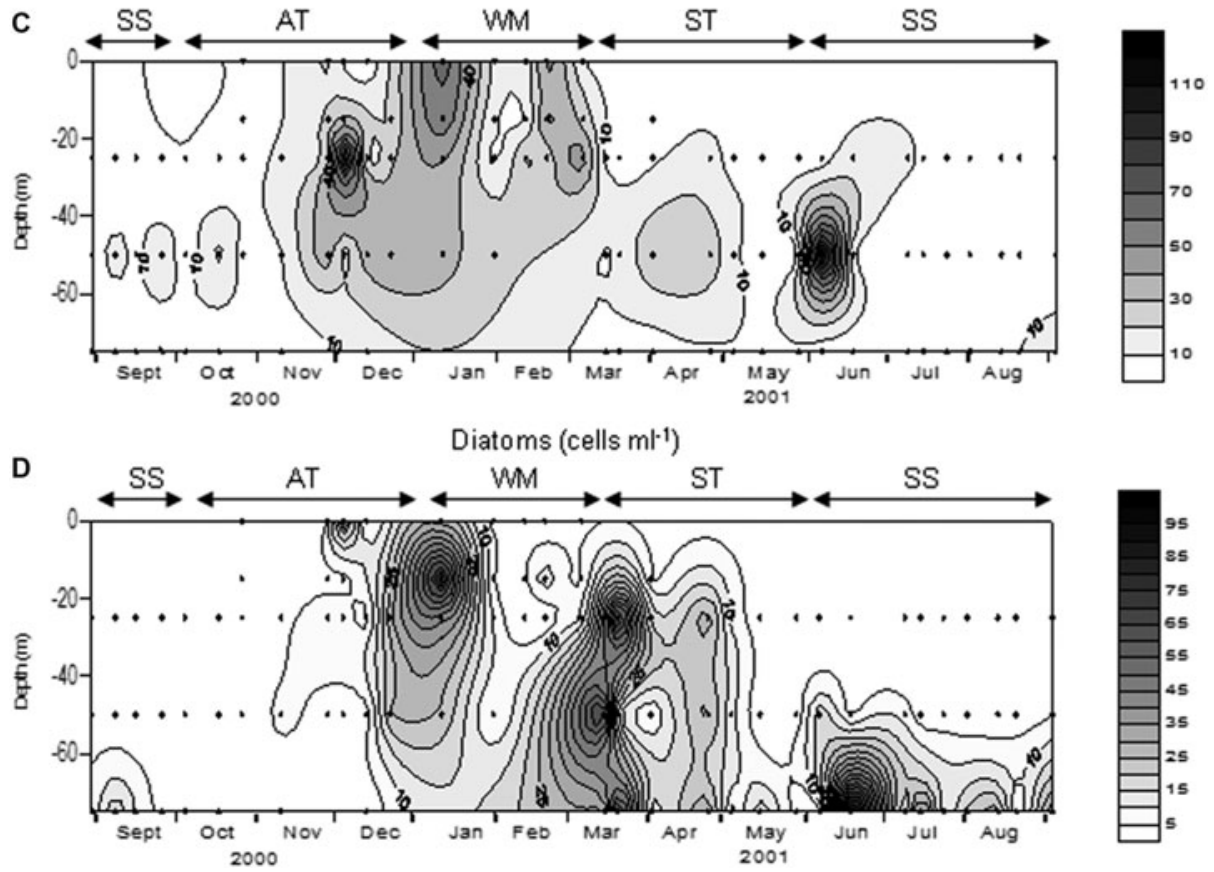

Fig. 6. Variation of dinoflagellates (A), undetermined flagellates (B), coccolithophores (C) and diatoms (D) during the study. Dots indicate the depths sampled for microscope counting. SS, Summer Stratification; AT, Autumn Transition; WM, Winter Mixing; ST, Spring Transition.

belonging to Margalef's Stage II (Margalef, 1963a), such as the genera Thalassionema, Rhizosolenia or Pseudo-nitzschia. According to Estrada et al. (2014), in recent AW Phaeocystis sp. is an important contribution to the blooms where diatoms do not proliferate (Estrada et al., 2014). But this was not our case, maybe because MW predominated in our early proliferations. A possible explanation for the absence of Stage I diatoms in our study in the beginning of the March and June blooms is that the sampling did not coincide with the proliferation of these species. However, at least in those two blooms, this is questionable because the silicate would have been depleted. Nevertheless, on these two dates the silicate concentrations in the chlorophyll maxima level were close to $2 \mu \mathrm{M}$, a concentration high enough for the development of diatom blooms (Egge \& Aknes, 1992; Brown et al., 2003). Presumably there was simply no development of this kind of species. Other studies found that E. huxleyi usually develops some time after the beginning of the bloom (Sprengel et al., 2002), especially after the development of diatoms (Iglesias-Rodríguez et al., 2002; Tyrrell \& Merico, 2004; Oguz \& Merico, 2006; Van Oostende et al., 2012). The appearance of E. huxleyi after the diatoms can be explained 


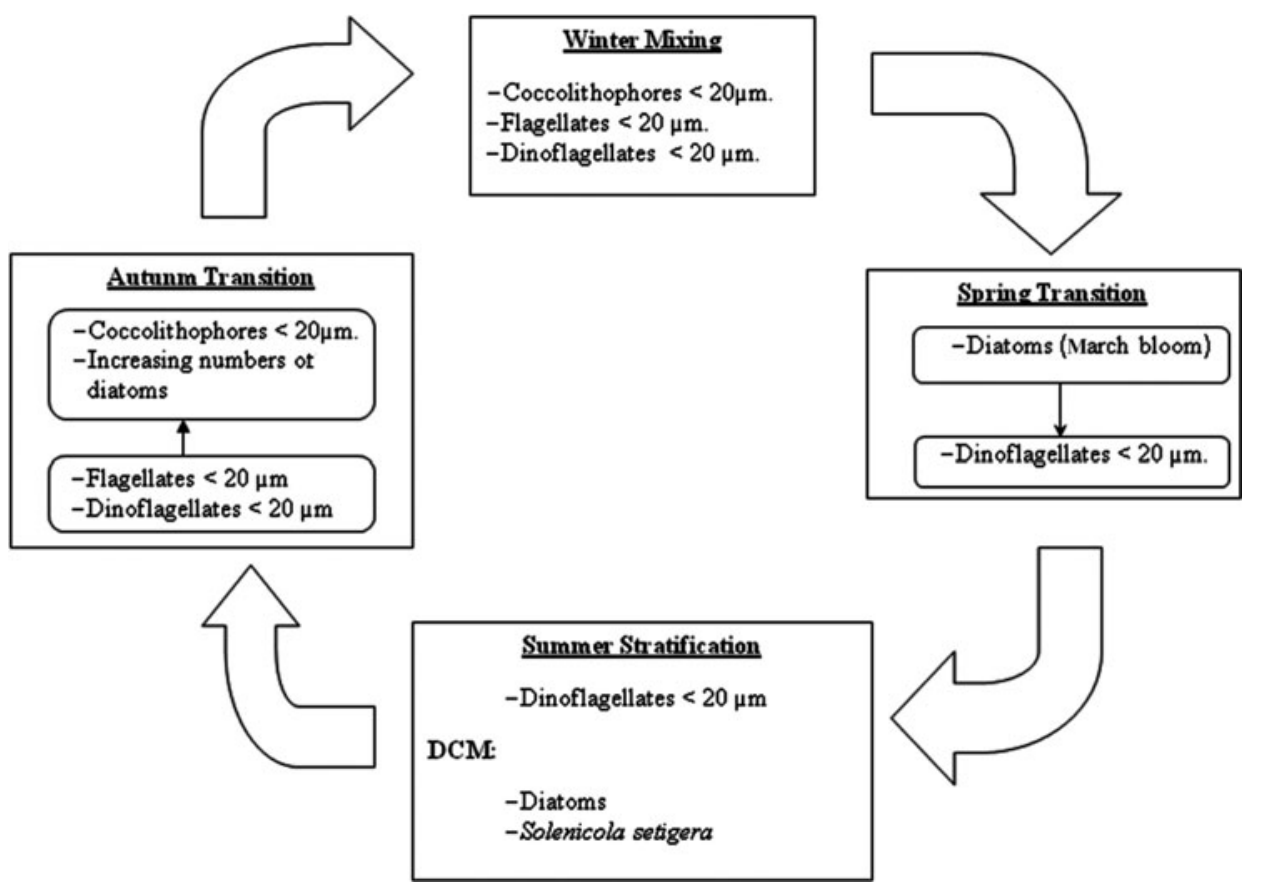

Fig. 7. Schematic representation of the variation of phytoplankton species and groups over the annual cycle.

by the fact that it requires vitamin $\mathrm{B}_{1}$ or thiamine (Tyrrell \& Merico, 2004). Moreover, it is unable to compete with diatoms in high nutrient conditions, since coccolithophores have lower nutrient uptake capacities when the concentration is high (Iglesias-Rodríguez et al., 2002). However, coccolithophores effectively compete with diatoms in semioligotrophic conditions (Iglesias-Rodríguez et al., 2002), as the former have a higher affinity for nitrogen and phosphate (Eppley et al., 1969). Therefore, the absence of fast-growing diatoms in the first stages of the March and June blooms were probably the result of a lack of sufficient nutrient concentration for its development, being substituted by coccolithophores, better adapted to a lower nutrient concentration. According to Bode et al. (2005) Skeletonema costatum and Thalassiosira spp. depend on the availability of silicate. Charles et al. (2005) reported high nutrient requirements for Skeletonema costatum, especially phosphate (minimum $>0.15 \mu \mathrm{M}-\mathrm{P}$ ). Other studies (Nogueira et al., 2000; Varela \& Prego, 2003; Aubry et al., 2004) found high densities of Skeletonema costatum associated with concentrations above $20 \mu \mathrm{M} \mathrm{NO}_{3}$ and $0.2 \mu \mathrm{M} \mathrm{PO}_{4}$, higher values than usual in our chlorophyll maxima of winter and spring. In addition to nutrient limitation, the absence of high turbulence, especially in June, could also explain the lack of diatoms during early blooms. High turbulence prevents the sedimentation of diatoms and hinders flagellate development due to cell damage (Smayda, 1997).

The presence of coccolithophores at the beginning of the proliferation raises interesting questions. Because of the vitamin $\mathrm{B}_{1}$ requirements, Emiliania huxleyi could not be a bloom precursor (early blooms) as they need previous biological activity (Tyrrell \& Merico, 2004). Nevertheless, the ecological importance of vitamin $B_{1}$ has not yet been determined (Paasche, 2002). In fact this compound could originate from the nanoflagellates or bacteria that develop simultaneously with coccolithophores.

\section{CDNCLUSIONS}

This is the first study on the annual cycle of phytoplankton on the Balearic Shelf, and was performed using an intensive sampling. We found the highest phytoplankton biomass for the period 1994-2003. This was related to the high convective mixing and the prevalence of northern waters during the cycle studied.

During the bloom conditions it highlights the presence of coccolithophores as bloom precursors. During no-bloom situations the phytoplankton community was mainly formed by small flagellates. In the most oligotrophic conditions dinoflagellates were dominant. During the Winter Mixing period different groups of nanoplanktonic flagellated forms prevailed, including coccolithophores, undetermined flagellates and dinoflagellates.

\section{ACKNDWLEDGEMENTS}

We would like to thank P. Sánchez, M. Serra, B. Salamanca and J.C. Alonso for their assistance during the sampling, and B. Amengual for the nutrient analysis. We are also grateful to Dr Antonio Bode and the anonymous referee for their valuable suggestions.

\section{FINANCIAL SUPPORT}

This work was supported by the Instituto Español de Oceanografía (project Hercule; J.V. fpi grant 2000) and the Spanish Ministry of Economy and Competitiveness (project MAFIA CTM2012-39587). 


\section{REFERENCES}

Alemany F., Quintanilla L., Vélez-Belchí P., García A., Cortés D. Rodríguez J.M., Fernández de Puelles M.L., González-Pola C. and López-Jurado J.L. (2010) Characterization of the spawning habitat of Atlantic bluefin tuna and related species in the Balearic Sea (Western Mediterranean). Progress in Oceanography 86, 21-38.

Armstrong F.A.K., Stern C.R. and Strickland J.D.H. (1967) The measurements of upwelling and subsequent biological processes by means of the Technicon Autoanalyzer and associated equipment. Deep Sea Research 14, 381-389.

Aubry F.B., Berton A., Bastianini M., Socal G. and Acri F. (2004) Phytoplankton succession in a coastal area of the NW Adriatic, over a 10-year sampling period (1990-1999). Continental Shelf Research 24, $97-115$.

Bode A., Álvarez-Ossorio M.T., González N., Lorenzo J., Rodríguez C. Varela M. and Varela M.M. (2005) Seasonal variability of plankton blooms in the Ría de Ferrol (NW Spain): II. Plankton abundance, composition and biomass. Estuarine Coastal and Shelf Science 63, 285-300.

Brown L., Sanders R., Savidge G. and Lucas C.H. (2003) The uptake of silica during the spring bloom in the Northeast Atlantic Ocean. Limnology and Oceanography 48, 1831-1845.

Charles F., Lantoine F., Brugel S., Chrétiennot-Dinet M.J., Quiroga I. and Rivière B. (2005) Seasonal survey of the phytoplankton biomass, composition and production in a littoral NW Mediterranean site, with special emphasis on the picoplanktonic contribution. Estuarine Coastal and Shelf Science 65, 199-212.

Duarte C.M., Agustí S., Kennedy H. and Vaqué D. (1999) The Mediterranean climate as a template for the Mediterranean marine ecosystems: the example of the sortheast Spanish littoral. Progress in Oceanography 44, 245-277.

Egge J.K. and Aksnes D.L. (1992) Silicate as regulating nutrient in phytoplankton competition. Marine Ecology Progress Series 83, 281-289.

Eppley R.W., Rogers J.N. and McCarthy J.J. (1969) Half saturation constant for uptake of nitrate and ammonium by marine phytoplankton. Limnology and Oceanography 14, 912-920.

Estrada M., Latasa M., Emelianov M., Gutiérrez-Rodríguez A., Fernández-Castro B., Isern-Fontanet J., Mouriño-Carballido B., Salat J. and Vidal M. (2014) Seasonal and mesoscale variability of primary production in the deep winter-mixing region of the NW Mediterranean. Deep-Sea I 94, 45-61.

Estrada M., Marrasé C., Latasa M., Berdalet E., Delgado M. and Riera T. (1993) Variability of deep chlorophyll maximum characteristics in the Northwestern Mediterranean. Marine Ecology Progress Series 92, 289-300.

Estrada M. and Salat J. (1989) Phytoplankton assemblages of deep and surface water layers in a Mediterranean frontal zone. In Ros J.D. (ed.) Topics in marine biology. Barcelona: Scientia Marina, Volume 53, pp. $203-214$.

Estrada M., Vives F. and Alcaraz M. (1985) Life and the productivity of the Open Sea. In Margalef R. (ed.) Western Mediterranean. Oxford: Pergamon Press, pp. 149-197.

Fernández de Puelles M.L., Alemany F. and Jansá J. (2007) Zooplankton time-series in the Balearic Sea (Western Mediterranean): variability during the decade 1994-2003. Progress in Oceanography 74, 329-354

Fernandez de Puelles M.L., Jansá J., Gomis C., Gras D. and Amengual B. (1997) Variación de las principales variables oceanográficas y planctónicas en una estación nerítica del mar Balear. Boletín del Instituto Español de Oceanografía 13, 13-33.
Fernández de Puelles M.L., Gras D. and Hernández-León S. (2003) Annual cycle of zooplankton biomass, abundance and species composition in the neritic area of the Balearic Sea, Western Mediterranean. Pubblicazioni della Stazione Zoologica di Napoli I Marine Ecology 23, $1-17$.

Fernández de Puelles M.L. and Molinero J.C. (2007) North Atlantic climate control on plankton variability in the Balearic Sea, Western Mediterranean. Geophysical Research Letters 34, L04608. doi: 10.1029/2006GLo28354.

Fernández de Puelles M.L., Valencia J., Jansá J. and Morillas A. (2004) Hydrographical characteristics and zooplankton distribution in the Mallorca channel (Western Mediterranean): spring 2001. ICES Journal of Marine Science 61, 654-666.

Guerreiro C., Oliveira A., Stigter H., Cachao M., Sá C., Borges C., Cros L. Santos A., Fortuño J.M. and Rodrigues A. (2013) Late winter coccolithophore bloom off central Portugal in response to river discharge and upwelling. Continental Shelf Research 59, 65-83.

Gutiérrez-Rodríguez A., Latasa M., Estrada M, Vidal M and Marrasé C. (2010) Carbon fluxes through major phytoplankton groups during the spring bloom and post-bloom in the Northwestern Mediterranean Sea. Deep-Sea Research I 57, 486-500.

Holm-Hansen O., Lorenzen J., Holmes R.W. and Strickland J.D.H (1965) Fluorometric determination of chlorophyll. ICES Journal du Conseil 30, 3-15.

Iglesias-Rodríguez M.D., Brown C.W., Doney S.C., Kleypas J., Kolber D., Kolber Z., Hayes P.K. and Falkowski P.G. (2002) Representing key phytoplankton functional groups in ocean carbon cycle mode: Coccolithophorids. Global Biogeochemical Cycles 16, 1-19.

Jansá J. (2008) ¿És el mar Balear un mar oligotròfic?. Sintesi sobre les dades de clorofil-la fitoplànctonica obtinguda des de 1974 al Centre Oceanogràfic de Balears (IEO). Estudis Baleàrics (IEB) 88/89, 125-136.

Legendre L. and Rassoulzadegan F. (1995) Plankton and nutrient dynamics in marine waters. Ophelia $41,153-172$.

López-Jurado J.L., García Lafuente J. and Álvarez A. (1996) Water exchanges in the Balearic Sea. CIESM Science Series $n_{2}^{\circ}$ Bulletin de l'Institut océanographique, Monaco 17, 41-63.

Margalef R. (1958) Temporal succession and spatial heterogeneity in phytoplankton. In Buzzi-Traverso A.E. (ed.) Perspectives in marine biology. Berkeley, CA: University of California Press, pp. 323-349.

Margalef R. (1963a) El ecosistema pelágico de un área costera del Mediterráneo Occidental. Memorias de la Real Academia de Ciencias $y$ Artes de Barcelona 35, 1-48.

Margalef R. (1963b) Modelos simplificados del ambiente marino para el estudio de la sucesión y distribución del fitoplancton y del valor indicador de sus pigmentos. Investigaciones Pesqueras 23, 11-52.

Mergulhao L.P., Mohan R., Murty V.S.N., Guptha M.V.S. and Sinha D.K. (2006) Coccolithophores from the central Arabian Sea: sediment trap results. Journal of Earth System Science 115, 415-428.

Nogueira E., Ibanez F. and Figueiras F.G. (2000) Effect of meteorological and hydrographic disturbances on the microplankton community structure in the Ría de Vigo (NW Spain). Marine Ecology Progress Series 203, 23-45

Oguz T. and Merico A. (2006) Factors controlling the summer Emiliania huxleyi bloom in the Black Sea: a modeling study. Journal of Marine Systems 59, 173-188.

Paasche E. (2002) A review of the coccolithophorid Emilania huxleyi (Prymnesiophyceae), with particular reference to growth, coccoltih formation, and calcification-photosynthesis interactions. Phycologia 40, 503-529. 
Pinot J.M., López-Jurado J.L. and Riera M. (2002) The CANALES experiment $(1996-1998)$. Interannual, seasonal, and mesoscale variability of the circulation in the Balearic Channels. Progress in Oceanography 55, 335-370.

Puigserver M. (2003) Aspectes ecòlogics $i$ taxonòmics del fitoplàncton a zones costaneres de la Mediterrània. PhD thesis. Universitat de les Illes Balears, Palma de Mallorca, Spain.

Ros M. and Miracle R. (1984) Variación estacional del fitoplancton del Mar Menor y su relación con la de un punto próximo en el Mediterráneo. Limnética 1, 32-42.

Silva A., Palma S. and Moita M.T. (2008) Coccolithophores in the upwelling waters of Portugal: four years of weekly distribution in Lisbon bay. Continental Shelf Research 28, 2601-2613.

Siokou-Frangou I., Christaki U., Mazzocchi M.G., Montresor M., Ribera d'Alcalà M., Vaqué D. and Zingone A. (2009) Plankton in the open Mediterranean Sea: a review. Biogeosciences Discussions 6, 11187-111293.

Smayda T.J. (1980) Phytoplankton species succession. In Morris I. (ed.) The physiological ecology of phytoplankton. Oxford: Blackwell Scientific, pp. 493-570.

Smayda T.J. (1997) Harmful algal blooms: their ecophysiology and general relevance to phytoplankton blooms in the sea. Limnology and Oceanography 42, 1137-1153.

Sournia A.E. (ed). (1978) Phytoplankton manual. Monographs on Oceanographic Methodology. Volume 6. Paris: UNESCO.

Sprengel C., Baumann K.H., Henderiks J., Henrich R. and Neuer S. (2002) Modern coccolithophore and carbon sedimentation along a productivity gradient in the Canary Islands Region: seasonal export production and surface accumulation rates. Deep-Sea Research II 49, 3577-3598.

Tyrrell T. and Merico A. (2004) Emiliania huxleyi: bloom observations and the conditions that induce them. In Thierstein H.R. and Young J.R. (eds) Coccolithophores from molecular processes to global impact. New York, NY: Springer-Verlag, pp. 75-97.

UNESCO (1966) Determination of photosynthetic pigment. Monographs on Oceanographic Methodology. Volume 1. Paris: SCOR/UNESCO, UNESCO, pp. 11-18.

Valencia-Vila J. (2013) Variación estacional del fitoplancton en una estación nerítica del Canal de Mallorca (Mediterráneo Occidental). PhD. thesis. A Coruña, Galicia, Spain: Universidade da Coruña.

Varela M. and Prego R. (2003) Hydrography and phytoplankton in an isolated and non-pristine ría area: the A Coruña Harbor (NW Spain). Acta Oecologica 24, 113-124.

and

Van Oostende N., Harlay J., Vannelslander B., Vyverman W. and Sabbe K. (2012) Phytoplankton community dynamics during late spring coccolithophore blooms at the continental margin of the Celtic Sea (North East Atlantic, 2006-2008). Progress in Oceanography 104, 1-16.

\section{Correspondence should be addressed to:}

J. Valencia-Vila

Instituto Español de Oceanografía, Paseo Alcalde Vázquez, 10. 15001, A Coruña, Spain email: joaquin.valencia@co.ieo.es 